\title{
EFFECT OF COMBINED MANUAL THERAPY ON NECK PAIN AND QUALITY OF LIFE IN POST - OPERATIVE HEAD AND NECK CANCER PATIENTS - A PRE - POST EXPERIMENTAL STUDY
}

\section{Renu Pattanshetty ${ }^{1}$, Erohit khanna ${ }^{* 2}$.}

${ }^{1}$ Associate Professor and Head, Department of Oncology Physiotherapy, KLEU Institute of Physiotherapy, Belagavi, Karnataka, India.

*2 Post graduate student (oncology physiotherapy), KLEU Institute of Physiotherapy, Belagavi, Karnataka, India.

\section{ABSTRACT}

Background: The burden of head and neck cancer in India has been increasing in recent years. Despite evidence that physical therapy exists throughout phases of treatment for head and neck cancer patients, combined treatment of manual therapy in the form of mobilization, muscle energy technique and soft tissue mobilization techniques are rarely available for clinical practice. Hence, the present study was taken up. Aim: To study the effect of combined manual therapy in form of mobilization, Muscle energy technique and soft tissue mobilization on neck pain, quality of life, mobility in Head and Neck Cancer Patients.

Settings and Design: The experimental study was undertaken in a tertiary care referral hospital over a period of three months.

Materials and Methods: A total of fifteen(15) subjects including eleven (11) males and four (4) females post operative head and neck cancer subjects were given combined manual therapyin the form of cervical mobilization, muscle energy technique and Soft tissue Mobilization for duration of a week during the hospitalisation phase. Pain was assessed using Numeric pain rating Scale, Range of motion of cervical joint, shoulder joint and Temporomandibular joint, Functional assessment was done using Neck disability index and FACT H\&N Questionnaire. Statistical Analysis was done using SPSS Version 0.21. Students dependent ' $t$ ' test was used to analyse the pre and post treatment difference in all outcome measures.

Results: The study demonstrated improvement in all the outcome measures in the study, the significant difference was seen in with pd"0.001 except cervical rotation and shoulder range of motion.

Conclusion: The study demonstrated Pain reduction, Improvement in Cervical, TMJ and shoulder range of motion, Improved Quality of life and reduction in disability following combined manual therapy approach.

KEY WORDS: Head and Neck Cancer, Cervical Mobilization, Muscle energy technique, Soft tissue mobilization, quality of life, manual therapy, TMJ.

Address for correspondence: Dr. Erohit khanna, Post graduate student (oncology physiotherapy), KLEU Institute of Physiotherapy, Belagavi - 590010, Karnataka, India.

Contact No.: +919611726520 E-Mail: kerohit@gmail.com

\begin{tabular}{|l|l|}
\hline \multicolumn{3}{|c|}{ Access this Article online } \\
\hline Quick Response code & \multicolumn{1}{|c|}{ International Journal of Physiotherapy and Research } \\
ISSN 2321- 1822
\end{tabular}

\section{INTRODUCTION}

Cancer is an uncontrolled growth of cells, which invade and spread to distant sites of the body [1]. The cell of origin for a given neoplasm (benign or malignant) is its histogenesis. In head and neck cancer, the most common type of malignant is the one that arises from the surface i.e squamous epithelium [2]. 
The global incidence of cancers in oral cavity, pharynx and larynx is about 500,000 cases per year with mortality of 270,000 cases per year. At least $75 \%$ of head and neck cancers are attributable to a combination of cigarette smoking and alcohol drinking [3]. In India, tobacco smoking and alcohol drinking are thought to contribute about $35 \%$ of oral cavity cancers among men while paan chewing accounted for $45 \%$ of oral cavity cancers among men and $87 \%$ of oral cavity cancers among female [4].

Risks of head and neck cancer include poor oral hygiene, painful or ill-fitting dentures, exposure to organic chemicals, coal products, cement and paint, battery plant work.

Head and neck cancer treatment includes several sequential treatment like surgical resection, chemotherapy or radiation therapy. Clinical features of post operative head and neck cancer subjects include pain, hoarsness of voice, coughing, trismus, decreased cervical and shoulder mobility, depression, anxiety, immobility, dysphagia, hearing impairem ent, lump in mouth, unexplained bleeding and ulcerative lesions [5].

Despite evidence, physical therapy exist throughout phases of treatment for head and neck cancer, Combined manual therapy in the form of mobilization, MET and soft tissue mobilization programs are rarely available for clinical practice [6]. Two case studies demonstrated positive effect of mobilization, MET, soft tissue mobilization, kinesiotaping and resistance exercises on cervical function in head and neck cancer $[7,8]$. The purpose of this experimental study was to treat post operative head and neck cancer with Combined Manual Therapy techniques in the form of Maitland Mobilisation, Muscle energy technique, and Cyriax soft tissue mobilization following surgeries with head and neck cancer to improve cervical and shoulder range of motion and quality of life.

\section{MATERIALS AND METHODS}

The study was conducted in a tertiary health care centre of Belagavi in Karnataka, for a duration of 3 months. Approval was sought from the Institutional Review Board. A written informed consent was obtained from fifteen adult male and female subjects with post-operative Head and Neck Cancer. The Inclusion Criteria was age above thirty years, TNM staging staging 1-3, with cervical and shoulder pain and restriction of movement. Subjects were excluded in the presence of any head and neck fractures, any neurological deficits, bone tumors or vertigo. A brief demographic data was obtained. Pre and post treatment assessment of pain was assessed with Numeric Pain Rating Scale, quality of life was assessed with FACT-H\&N Questionnaire, cervical and shoulder range of motion was assessed with universal goniometer and Temporomandibular joint for mouth opening with standard ruler (refer fig 3 ). The subjects were given physical therapy intervention for six sessions in a week and re assessment was done on the seventh day. Maitland mobilization, muscle energy technique and cyriax's soft tissue mobilisation was given. Haemodynamic status was constantly monitored during the intervention, In case patient experiencing any discomfort or tiredness, adequate amount of rest was provided and privacy of patient was respected.

Fig. 1: Consort flow chart.

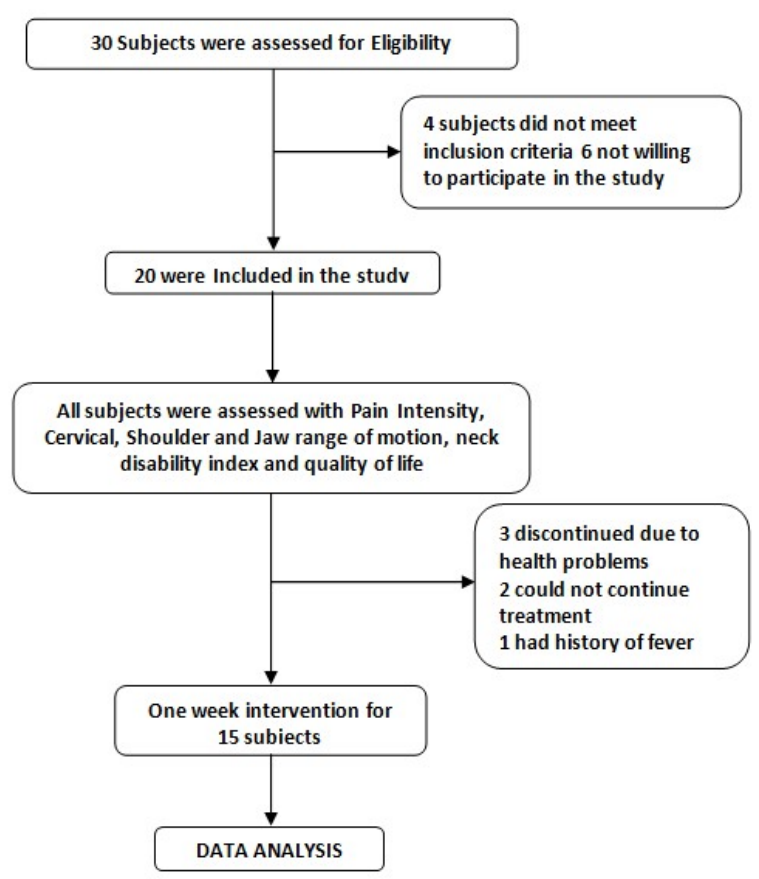

Procedure for maitland mobilisation (Cervical spine): Grade I and II Maitland mobilisation was given for 30 oscillation in 3 set (10 oscillation ) at each cervical level repeatedly.

To improve cervical lateral flexion, Patient is instructed to lie on back with head and neck 
beyond the head of couch. The therapist stands at head end to support the neck. This position isaltered so that left forearm lies behind the patients left ear almost under occiput and the right hand is brought forward so that the palm covers whole of the ear.

The mobilising force differs as the therapist moves round along the side the patients right shoulder to face diagonally across head. The final stage involves crouching to hug the patients head and the movement will be localised to a particular intervertebral level by the pressure ofpalmar surface of the index finger. This was only 30 oscillations with rest for few seconds between to avoid discomfort of patient.

To improve cervical rotation, patient is instructed to lie on back with head and neck beyond the head of couch.The therapist stands at the head end of the couch. The mobilizing force is posterior to anterior force and is directed along the left zygapophyseal joint plane of the cervical segment [9]. This was 30 oscillations with small amount of rest to avoid patient discomfort.

The choice is to use graded mobilizations of I and II was determined based on the low irritability and stiff dominance of the patient. Initial mobilizations was given as 3 set of 30 second intervals rest and progressed according to patient response to pain and comfort.

\section{Procedure for muscle energy technique:}

Muscle energy technique, as described by Greenman [10], is used toward the end range of newly acquired motion after mobilization session. All the subjects were asked to lie in supine lying position. The therapist stood at the head end of the bed. Therapist's index and middle finger of each hand was in contact with the pillar of the superior vertebra segment. Therapist palm and thenar eminence controlled the subject's head and cervical spine. Resistance was encountered with backward bending, side bending, and rotation. The subject was asked to resist movement when the therapist applied force in opposite direction. The subjects maintained resistance for approximately, 5 (five seconds) against an unyielding resistance imparted by the therapist.

Initially, muscle energy technique was given three to five repetitions and progressed according to subject's response to pain and comfort. Procedure for cyriax soft tissue technique: By end of the mobilisation and MET, soft tissue release was given to the patient according to his/her tolerance. The procedure involved lying down comfortably in supine, while the therapist stood at the side of the subject. External soft tissue mobilization was applied to structures of the neck and structures of the sub cranial region on the affected side. Initial contact in both regions is broad and superficial. This contact was from broad to superficial and progressed to a deeper, perpendicular application in order to more appropriately address the various soft tissue fibrosis and bony contour attachments [11].Transverse friction technique was applied to maximum soft tissue restriction. Intra-oral soft tissue mobilization was performed with great care in the area of lingual root of the tongue and its surrounding structures. The therapist wore surgical gloves while performing intraoral soft tissue mobilisation. Sustained mild pressure techniques to the same area was assisted withactive lingual movement into lateral deviation performed by the subjects on the affected side This sequence of soft tissue mobilization was repeated 3 to 5 times per muscle. In case participant experienced severe pain, the treatment was stopped immediately.Special care was taken of suture site, by monitoring pain at regular interval and avoiding mobilising immediately after dressing.

Fig. 1: Measurement of cervical range of motion using universal goniometer.

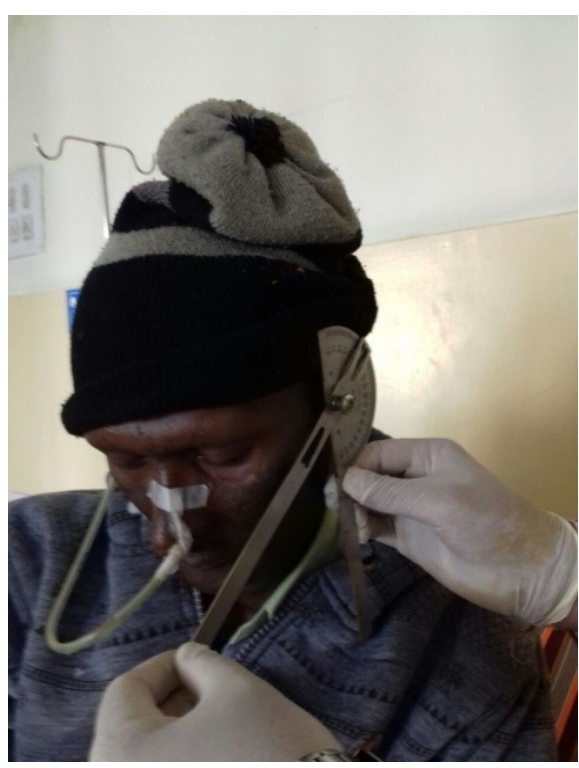


Fig. 2: Cervical Mobilisation, patient in supine lying, therapist stabilising hand on subject occiput and mobilising hand zygophaes.

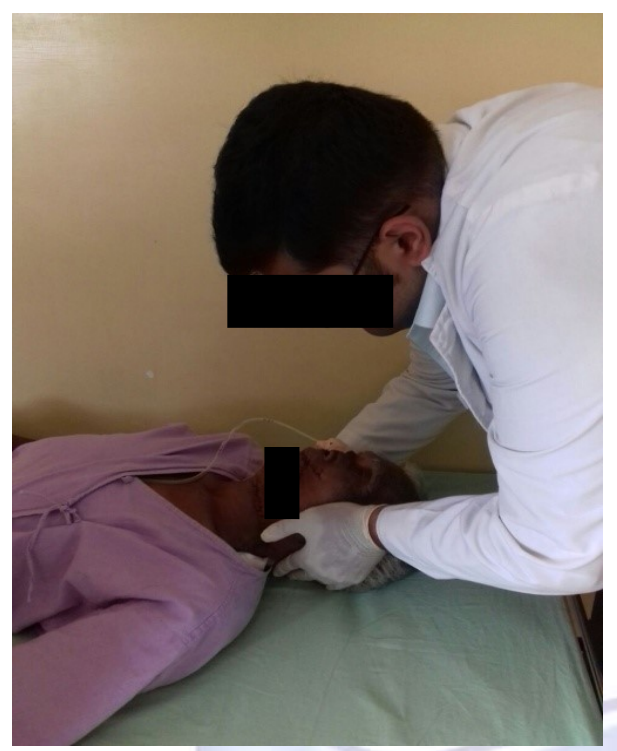

Fig. 3: Measurement of Jaw opening.

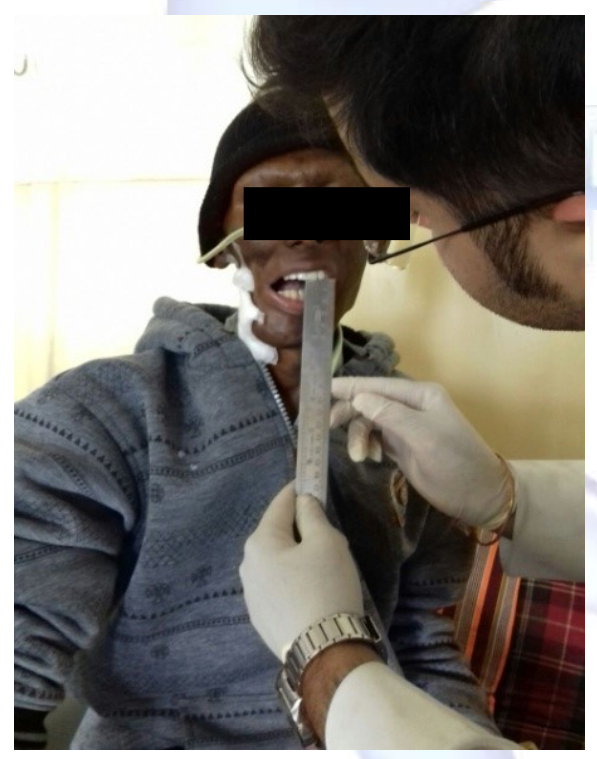

Fig. 4: Intra -Oral Soft tissue mobilisation.

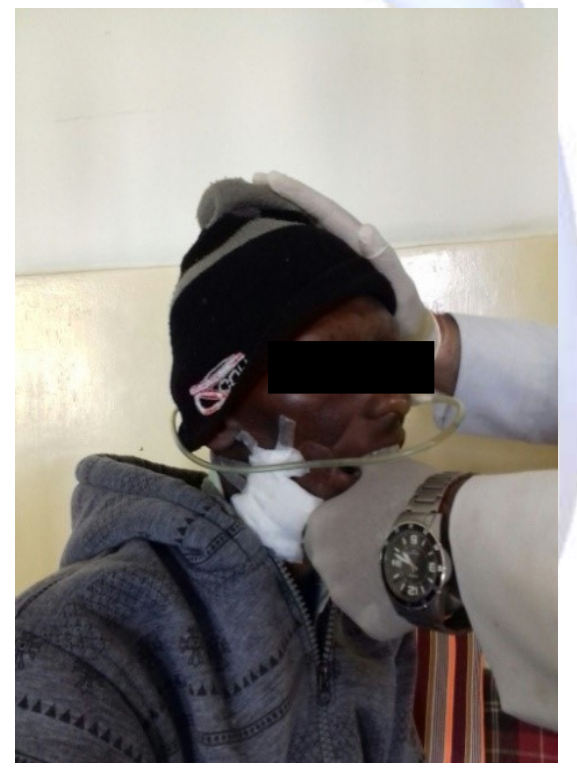

\section{RESULTS}

The raw data of fifteen subjects was analysed and subjected for statistical analysis using SPSS software version 21 to compare pre and post treatment scores using Students Dependent ' $t$ ' test. ' $p$ ' values $\leq 0.05$ is considered statistically significant with alpha error of $5 \%$.

The demographic data included more number of males 11 (eleven) as compared to females, 05(five) showing males were found to be more affected with head and neck cancer. The mean age group of all the subjects in the study was $54.3 \pm 20.4$ years and most of them suffered from cancer of buccal mucosa, cancer of tongue and base of tongue (Refer Table 1). There were significant changes seen pre and post intervention for pain intensity, quality of life and neck disability index with $p$ value $\leq 0.0001$ (Refer Table 2).There were significant changes observed with $p$ value $\leq 0.05$ in cervical range of motion except cervical rotation, shoulder range of motion improved but was not statistically significant. However, jaw range of motion improved significantly.

Tables 1: Demographic Data of all the study groups.

\begin{tabular}{|c|c|c|}
\hline $\begin{array}{l}\text { Demographic } \\
\text { characteristics }\end{array}$ & $\begin{array}{c}\text { No of } \\
\text { patients }\end{array}$ & $\%$ of patients \\
\hline $\begin{array}{c}\text { Age } \\
(\leq 50 y r s: \geq 50 y r s)\end{array}$ & 7:08 & 46.67: 53.33 \\
\hline Gender F:M & $4: 11$ & 26.67: 73.33 \\
\hline
\end{tabular}

Table 2: Comparison of pretest and posttest scores of outcome measures by dependent $t$ test. ${ }^{*} p<0.05$

\begin{tabular}{|c|c|c|c|c|c|}
\hline & Pre value & Post value & mean \pm SD & Paired t & P-value \\
\hline NPRS & $4.80 \pm 1.47$ & $3.07 \pm 1.44$ & 1.73 & 8.404 & $0.0001^{*}$ \\
\hline NDI & $16.67 \pm 9.05$ & $11.87 \pm 6.06$ & 4.8 & 5.2672 & $0.0001 *$ \\
\hline FACT H\&N & $65.87 \pm 7.84$ & $97.27 \pm 10.47$ & -31.4 & -12.3405 & $0.0001 *$ \\
\hline
\end{tabular}

Table 3: Comparison of pretest and posttest scores of parameters of cervical range of motion (in degrees) by dependent t test. ${ }^{*} \mathrm{p}<0.05$

\begin{tabular}{|c|c|c|c|c|}
\hline Variables & $\begin{array}{l}\text { Time } \\
\text { points }\end{array}$ & Mean & Paired $t$ & P-value \\
\hline \multirow{2}{*}{ Cervical flexion } & Pretest & $39.60 \pm 4.03$ & \multirow{2}{*}{-4.3156} & \multirow{2}{*}{$0.0007^{*}$} \\
\hline & Posttest & $42.40 \pm 2.56$ & & \\
\hline \multirow{2}{*}{ Cervical extension } & Pretest & $38.13 \pm 10.71$ & \multirow{2}{*}{-3.2404} & \multirow{2}{*}{$0.0059^{*}$} \\
\hline & Posttest & $39.13 \pm 9.83$ & & \\
\hline \multirow{2}{*}{$\begin{array}{l}\text { Right cervical } \\
\text { lateral flexion }\end{array}$} & Pretest & $38.93 \pm 4.10$ & \multirow{2}{*}{-6.1235} & \multirow{2}{*}{$0.0001^{*}$} \\
\hline & Posttest & $40.87 \pm 4.19$ & & \\
\hline \multirow{2}{*}{$\begin{array}{c}\text { Left cervical lateral } \\
\text { flexion }\end{array}$} & Pretest & $40.47 \pm 3.64$ & \multirow{2}{*}{-4.802} & \multirow{2}{*}{$0.0003^{*}$} \\
\hline & Posttest & $42.33 \pm 3.27$ & & \\
\hline \multirow{2}{*}{$\begin{array}{l}\text { Right cervical } \\
\text { rotation }\end{array}$} & Pretest & $51.80 \pm 11.21$ & \multirow{2}{*}{-1.9743} & \multirow{2}{*}{0.0684} \\
\hline & Posttest & $52.27 \pm 11.23$ & & \\
\hline \multirow{2}{*}{$\begin{array}{l}\text { Left cervical } \\
\text { rotation }\end{array}$} & Pretest & $51.80 \pm 10.11$ & \multirow{2}{*}{-1.6253} & \multirow{2}{*}{0.1264} \\
\hline & Posttest & $52.47 \pm 9.60$ & & \\
\hline
\end{tabular}


Table 4: Comparison of pretest and posttest scores of parameters of shoulder range of motion (in degrees) by dependent $t$ test.

\begin{tabular}{|c|c|c|c|c|}
\hline Variables & $\begin{array}{l}\text { Time } \\
\text { points }\end{array}$ & Mean $\pm S D$ & Paired $t$ & P-value \\
\hline \multirow{2}{*}{$\begin{array}{l}\text { Right shoulder } \\
\text { flexion }\end{array}$} & Pretest & $174.67 \pm 7.43$ & \multirow{2}{*}{-1.7398} & \multirow{2}{*}{0.1038} \\
\hline & Posttest & $176.00 \pm 5.41$ & & \\
\hline \multirow{2}{*}{ Left shoulder flexion } & Pretest & $174.00 \pm 7.37$ & \multirow{2}{*}{--} & \multirow{2}{*}{-} \\
\hline & Posttest & $174.00 \pm 7.37$ & & \\
\hline \multirow{2}{*}{$\begin{array}{l}\text { Right shoulder } \\
\text { flexion }\end{array}$} & Pretest & $54.67 \pm 5.16$ & \multirow{2}{*}{-1} & \multirow{2}{*}{0.3343} \\
\hline & Posttest & $54.80 \pm 5.06$ & & \\
\hline \multirow{2}{*}{$\begin{array}{l}\text { Left shoulder } \\
\text { extension }\end{array}$} & Pretest & $57.33 \pm 5.94$ & \multirow{2}{*}{-1} & \multirow{2}{*}{0.3343} \\
\hline & Posttest & $57.67 \pm 4.95$ & & \\
\hline \multirow{2}{*}{$\begin{array}{l}\text { Right shoulder } \\
\text { abduction }\end{array}$} & Pretest & $170.67 \pm 10.33$ & \multirow{2}{*}{-1.1932} & \multirow{2}{*}{0.2526} \\
\hline & Posttest & $171.47 \pm 9.61$ & & \\
\hline \multirow{2}{*}{$\begin{array}{c}\text { Left shoulder } \\
\text { abduction }\end{array}$} & Pretest & $240.00 \pm 254.59$ & \multirow{2}{*}{0.986} & \multirow{2}{*}{0.3409} \\
\hline & Posttest & $174.20 \pm 7.58$ & & \\
\hline \multirow{2}{*}{$\begin{array}{l}\text { Right shoulder } \\
\text { adduction }\end{array}$} & Pretest & 0 & \multirow{2}{*}{ No Difference } & \multirow{2}{*}{$\begin{array}{c}\text { No } \\
\text { Difference }\end{array}$} \\
\hline & Posttest & 0 & & \\
\hline \multirow{2}{*}{$\begin{array}{l}\text { Left shoulder } \\
\text { adduction }\end{array}$} & Pretest & 0 & \multirow{2}{*}{ No Difference } & \multirow{2}{*}{$\begin{array}{c}\text { No } \\
\text { Difference }\end{array}$} \\
\hline & Posttest & 0 & & \\
\hline \multirow{2}{*}{$\begin{array}{l}\text { Right shoulder } \\
\text { external rotation }\end{array}$} & Pretest & $79.33 \pm 2.58$ & \multirow{2}{*}{ No Difference } & \multirow{2}{*}{$\begin{array}{c}\text { No } \\
\text { Difference }\end{array}$} \\
\hline & Posttest & $79.33 \pm 2.58$ & & \\
\hline \multirow{2}{*}{$\begin{array}{l}\text { Left shoulder } \\
\text { external rotation }\end{array}$} & Pretest & $80.67 \pm 2.58$ & \multirow{2}{*}{-} & \\
\hline & Posttest & $80.67 \pm 2.58$ & & \\
\hline \multirow{2}{*}{$\begin{array}{l}\text { Right shoulder } \\
\text { internal rotation }\end{array}$} & Pretest & $67.00 \pm 4.14$ & \multirow{2}{*}{-1.7448} & \multirow{2}{*}{0.1029} \\
\hline & Posttest & $69.47 \pm 6.39$ & & \\
\hline \multirow{2}{*}{$\begin{array}{l}\text { Left shoulder } \\
\text { internal rotation }\end{array}$} & Pretest & $70.00 \pm 0.00$ & -1 & 0.3343 \\
\hline & Posttest & $70.33 \pm 1.29$ & -1 & \\
\hline
\end{tabular}

Table 5: Comparison of pretest and posttest scores of parameters of jaw opening (in $\mathrm{mm}$ ) by dependent $\mathrm{t}$ test.

\begin{tabular}{|c|c|c|c|c|}
\hline Variables & $\begin{array}{c}\text { Time } \\
\text { points }\end{array}$ & Mean & Paired t & P-value \\
\hline \multirow{2}{*}{ Jaw opening } & Pretest & $29.40 \pm 5.69$ & \multirow{2}{*}{-9.4309} & $0.0001^{*}$ \\
\cline { 2 - 4 } & Posttest & $31.80 \pm 5.35$ & & \\
\hline \multirow{2}{*}{$\begin{array}{c}\text { Jaw lateral } \\
\text { deviation }\end{array}$} & Pretest & $5.33 \pm 2.55$ & \multirow{2}{*}{-5.2643} & $0.0001^{*}$ \\
\cline { 2 - 5 } & Posttest & $6.47 \pm 2.59$ & & \\
\hline
\end{tabular}

$* p<0.05$

\section{DISCUSSION}

The present study aimed to evaluate the effectiveness of combined manual therapy viz. Maitland cervical mobilization, soft tissue mobilization and muscle energy technique on subjects with post operative head and neck cancer in relationship to pain, quality of life, range of motion and disability level. Only a single case report has been conducted to study the effect of manual therapy, however the author suggested further need of randomized trials to know the effect of manual therapy approach on post operated cancer patients. The rationale remains same unlike other approaches of manual therapy
Manual therapy has shown positive effect in reducing pain and improving range of motion in post operated breast cancer patients to reduce impairment. The present study proves the positive effect of manual therapy approach as safe and effective in post operated head and neck cancer proving the clinical approach.

Occurrence of head and neck cancer appears at middle age or later years of life, recent reports suggest the preponderance of head and neck cancer exists for the population between 50 and 70 years of age however, controversy has developed regarding the clinical course of head and neck cancer in youth [12]. Though the included subjects of head and neck cancer were few in the study, the distribution suggest males more prone of developing head and neck cancer due to cigarette smoking and smokeless tobacco in its various forms. The age group mainly affected were around fifty (50) years which proves the occurrence of head and neck cancer mainly in middle aged male individuals. Also, the type of cancer commonly seen in head and neck cancer included cancer of buccal mucosa, cancer of tongue, cancer of base of tongue, cancer of larynx, maxilla, oesophagus. The mean BMI in the study was 20.4 which suggest cancer subjects were nearly underweight but normal since they demonstrated history of weight loss. Studies suggest weight loss occur during radiotherapy course of treatment of head and neck cancer due to dry or sore mouth, difficulty while masticating and swallowing food, altered taste perception, missing meals or symptoms of uncontrollable nausea and constipation [13].

The use of Cancer therapy like radiation therapy and chemotherapy are known to induce fatigue leading to decreased physical performance, affecting activity of daily living and functional disability therefore neck disability and quality of life needs to be assessed at various intervals. They also complain of generalized pain, neck pain and reduced neck mobility. Subjects of head and neck cancer of TNM grade I-III mostly complained of fatigue and show lack of interest to perform exercises on daily basis. In such cases manual therapy is the best approach in hospitalised patients to reduce pain and improve range of motion within short period of time. 
Quality of life is particularly relevant for subject's with head and neck cancer because this is of the social interaction and emotional expression which depends on structural and functional integrity of the head and neck region. In the patients with advance disease, intensive medical treatment may lead to severe physical psychosocial sequel. Depression and other psychosocial morbidity have shown to occur frequently in these patients. Measurements of Quality of life of head and neck cancer patients may help to make decisions about the treatment, identify patients with severe physical and psychosocial morbidity and plan rehabilitation [14].

The Functional Assessment of Cancer Therapy for Head and Neck Cancer (FACT-H\&N) is one of a patient reported outcome measure that is used to asses health related quality of life in subjects undergoing cancer treatment particularly in head and neck cancer. This scale consisted of 27 items that assessed the physical well-being (PWB-7), social/family wellbeing (SWB-7), emotional well-being (EWB 6) and functional wellbeing (FWB 7). In addition to these items there 12 items that were primarily assessed the disease specific factor of head and neck cancer [15]. Results of the present study demonstrated statistically significant increase in quality of life demonstrated the statistically significant improvement inall the components of FACT H\&N which included physical wellbeing, the social /family wellbeing and the functional wellbeing. Emotional wellbeing scores did not demonstrate statistical improvement which may be due to worries and concern about their post intervention state. It is therefore, important to evaluate the Quality of Life in Cancer patients, particularly in head and neck cancer patients for longer duration.

Studies were conducted to determine the immediate effects of the central postero anterior (PA) mobilization technique on both pain and active cervical range of motion in patients with mechanical neck pain with central or bilateral symptoms. Results suggest the 'central PA' mobilization group obtained a significantly greater reduction in pain on the most painful movement than the 'random' mobilization group hence our study includes maitland mobilisation in central PA direction [16].

In head and neck cancer patients with range of motion restriction of neck and shoulder is one of common complication seen post surgery, Also, limited mouth opening due to pain and sutures is seen commonly in buccal mucosa and tongue cancer patients. The maitland mobilization was implemented for pain reduction, increase range of motion and restore normal arthrokinematic motion of the cervical spine [9]. Muscle energy technique was applied with aim to reduce pain, improve range of motion and normalize arthrokinematics of cervical joint [10]. Soft tissue mobilization is chosen to reduce pain and increase tissue extensibility [11]. Hence combined manual therapy approach worked effectively to improve the range. However, there was not much significant difference seen in cervical rotation this might be because of pain at the site of suture or fear on movement post surgery. However further study needs to be conducted to finalize the reason for limited shoulder mobility when cervical mobilization, muscle energy technique and soft tissue was given mainly for cervical joint and around temporomandibular joint.

A single case study was done on 45 year old male subject with head and neck cancer undergone radical neck dissection. The patient reported reduction in pain, improvement in range of motion, reduced disability, improved strength and is returned to work after a week intervention, hence combined manual therapy techniques in the present study intervention is for a week based on findings in supportive literature [6].

Mobilization is found to reduce pain, the aim of mobilization included enhancement of passive physiologic motions within painfree limit [16]. However there is not much significant difference seen in cervical rotation and shoulder range of motion when compared to the case study. The reason of not significant changes may be application of grade I and II maitland mobilization and assessment of range of motion within a week. In the present study measurable effect is seen with muscle energy technique with respect to mobility and reduction of disability. MET is found to increase cervical range of motion in previous study were MET was given 
for four weeks for flexion, extension, side bending and rotation ${ }^{17}$. Soft tissue mobilization physiological response includes removal of pain mediators, tissue revascularization and easing as muscle guarding. The positive impact is seen with reduction of pain and improved quality of life ${ }^{6}$. The role of soft tissue mobilisation is to restore the tissue's ability to cope with functional loading. Specific soft tissue mobilization (SSTM) uses specific, graded and progressive application of force by the use of physiological, accessory or combined techniques either to promote collagen synthesis, orientation and bonding in the early stages of the healing process, or to promote changes in the viscoelastic response of the tissue in the later stages of healing. SSTM should be applied in combination with rehabilitation regimes to restore the kinetic control of the tissue [18]. It is not uncommon for a therapist to become reluctant in applying safe and effective manual therapy techniques in clinic while treating a patient with cancer. As noted previously, prudent judgment against harmful interventions in situations of active and/or malignant cancers should always be exercised. However, in cases where the cancer has been completely eradicated through surgery, appropriate manual therapy techniques may be helpful in aiding and enhancing the patient's recovery and return to work. Current literature already demonstrates benefits through the use of physical therapy for this patient population; however, new research is needed in a larger, controlled design to further determine a true cause and effect relation between or among the chosen interventions presented. On the present study it can be concluded that Cervical maitland mobilization, muscle energy technique and soft tissue technique as a combined manual therapy is a effective approach to treat patients with head and neck cancer post surgery for reducing pain, improving range of motion, reducing level of disability and improving quality of life within short duration of time. As the study was done for first time in larger population compared to case study, the positive effect of manual therapy can be used to treat post operative cancer patients. However the limitation of the study were that there was no follow up and no long term effect of the manual therapy was studied.

Int J Physiother Res 2017;5(6):2552-59. I ISSN 2321-1822

\section{ACKNOWLEDGEMENTS}

The authors would like to thank the Medical Director of the tertiary care hospital, Belagavi for allowing us to carry out this trial. The authors would also like to thank all the participants in the study.

\section{Conflicts of interest: None}

\section{REFERENCES}

[1]. World Health Organization. Cancer. WHO definition of palliative care.

[2]. Harrison LB, Sessions RB, Hong WK, editors. Head and neck cancer: a multidisciplinary approach. Lippincott Williams \& Wilkins; 2009.

[3]. Kulkarni MR. Head and neck cancer burden in India. Int J Head and Neck Surg. 2013 Jan;4(1):29-35.

[4]. Datta S, Chaturvedi P, Mishra A, Pawar P. A review of Indian literature for association of smokeless tobacco with malignant and premalignant diseases of head and neck region. Indian J Cancer 2014; $51: 200-8$

[5]. Cassidy J, Bissett D.,OBE, R.A.S.,Payne M, MorrisStiff $G$, editors. Oxford handbook of oncology. OUP Oxford; 2015 Aug 13

[6]. Gugliotti M. The use of mobilization, muscle energy technique, and soft tissue mobilization following a modified radical neck dissection of a patient with head and neck cancer. Rehabilitation Oncology. 2011 Jan 1;29(1):3-8.

[7]. Carter BC. Physical therapy treatment for a patient with complex rehabilitation needs during and after chemoradiation for head and neck cancer (Doctoral dissertation, FLORIDA GULF COAST UNIVERSITY).

[8]. McNeely ML, Parliament M, Courneya KS, Haykowsky M. Resistance exercise for post dissection shoulder pain: Three case reports. Physiother Theory Prac. 2004;20:41-56

[9]. Maitland GD. Maitland's Vertebral Manipulation. 6th ed. London: Butterworth-Heinemann; 2001

[10]. Greenman PE. Principles of Manual Medicine. 3rd ed. Philadelphia, PA: Lippincott Williams \& Wilkins; 2003.

[11]. Cyriax JH. Cyriax's Illustrated Manual of Orthopaedic Medicine. 2nd ed. Woburn, MA: ButterworthHeinemann; 2000

[12]. Von Doersten PG, Cruz RM, Rasgon BM, Quesenberry Jr CP, Mlsinger Jr RL. Relation between age and head and neck cancer recurrence after surgery: a multivariate analysis. Otolaryngology-Head and Neck Surgery. 1995 Sep;113(3):197-203.

[13]. Lees J. Incidence of weight loss in head and neck cancer patients on commencing radiotherapy treatment at a regional oncology centre. European journal of cancer care. 1999 Sep;8(3):133-6.

[14]. Hassan SJ, Weymuller EA. Assessment of quality of life in head and neck cancer patients. Head \& neck. 1993 Nov 1;15(6):485-96. 
[15]. Ringash J, Bezjak A, O’sullivan B, Redelmeier DA. Interpreting differences in quality of life: the FACT$\mathrm{H} \& \mathrm{~N}$ in laryngeal cancer patients. Quality of Life Research. 2004 May 1;13(4):725-33.

[16]. Kanlayanaphotporn R, Chiradejnant A, Vachalathiti R. Immediate effects of the central posteroanterior mobilization technique on pain and range of motion in patients with mechanical neck pain. Disability and rehabilitation. 2010 Jan 1;32(8):622-8.

[17]. Schenk R, Adelman K, Rousselle J. The effects of muscle energy technique on cervical range of motion. Journal of manual \& manipulative therapy. 1994 Jan 1;2(4):149-55.
[18]. Hunter G. Specific soft tissue mobilization in the management of soft tissue dysfunction. Manual Therapy. 1998 Feb 28;3(1):2-11.

\footnotetext{
How to cite this article:

Renu Pattanshetty, Erohit khanna. EFFECT OF COMBINED MANUAL THERAPY ON NECK PAIN AND QUALITY OF LIFE IN POST - OPERATIVE HEAD AND NECK CANCER PATIENTS - A PRE - POST EXPERIMENTAL STUDY. Int J Physiother Res 2017;5(6):2552-2559. DOI: 10.16965/ ijpr.2017.248
} 